Review Article

\title{
The Effect of Sandblasting on Bond Strength of Soft Liners to Denture Base Resins: A Systematic Review and Meta-Analysis of In Vitro Studies
}

\author{
Fahimeh Hamedirad $\left(\mathbb{D},{ }^{1}\right.$ Marzieh Alikhasi $\left(\mathbb{D},{ }^{2}\right.$ and Mahya Hasanzade ${ }^{3}{ }^{3}$ \\ ${ }^{1}$ Dental Materials Research Center, Health Research Institute, Babol University of Medical Sciences, Babol, Iran \\ ${ }^{2}$ Dental Research Center and Dental Implant Research Center, Dentistry Research Institute, Department of Prosthodontics, \\ School of Dentistry, Tehran University of Medical Sciences, Tehran, Iran \\ ${ }^{3}$ Dental Research Center, Dentistry Research Institute, Department of Prosthodontics, School of Dentistry, \\ Tehran University of Medical Sciences, Tehran, Iran \\ Correspondence should be addressed to Marzieh Alikhasi; m_alikhasi@yahoo.com and Mahya Hasanzade; mahya_hasanzade@ \\ yahoo.com
}

Received 18 June 2021; Revised 18 October 2021; Accepted 23 November 2021; Published 22 December 2021

Academic Editor: Carlos A. Munoz-Viveros

Copyright (c) 2021 Fahimeh Hamedirad et al. This is an open access article distributed under the Creative Commons Attribution License, which permits unrestricted use, distribution, and reproduction in any medium, provided the original work is properly cited.

\begin{abstract}
Objectives. This study aimed to evaluate the effect of sandblasting on the bond strength of denture base resin to soft liners. Materials and Methods. This report follows the Preferred Reporting Items for Systematic Reviews and Meta-Analyses (PRISMA) statement. PubMed, Embase, Cochrane, Scopus, and OpenGrey databases were searched for in vitro studies that compared sandblasting with no treatment in terms of the tensile, shear, and peel bond strength of resilient lining materials (acrylic-based or silicone-based) to polymethyl methacrylate denture base resin. Based on the outcome, the analysis was carried out in three groups of tensile, shear, and peel bond strength. Subgroup analysis was done for the effect of size of particles on sandblasting, blasting pressure, and type of soft liner whenever possible. Heterogeneity was evaluated among the studies, and meta-analysis was performed with random effect models $(p<.05)$. Results. After screening, 16 articles met the inclusion criteria for meta-analyses. No treatment showed significantly higher tensile $(p<0.001)$ or peel $(p=0.04)$ bond strength, although shear bond strength of sandblasted resin was significantly better $(p=0.008)$. Results of subgroup analyses of particle size favored the control group in $50 \mu \mathrm{Al}_{2} \mathrm{O}_{3}$ particle size $(p<0.001)$. In analyses of blasting pressure, the control group had significantly better tensile bond strength than specimens with blasting pressure $\leq 1$ bar $(p<0.001)$ while specimens with blasting pressure beyond 1 bar showed significantly more tensile strength than control group $(p=0.03)$. In silicon-based liners, groups without any surface treatment had significantly higher tensile bond strength $(p<0.001)$. Conclusion. According to the in vitro studies, sandblasting would not lead to significant increase in bond strength of soft liner to the denture base resin.
\end{abstract}

\section{Introduction}

Prolonged use of dentures is common among elderly patients. It could cause denture soreness and serve bone resorption [1]. Resilient lining materials are used to distribute the pressure equally and prevent localization of force by a cushion effect under the denture bases [2-11]. Relining materials offer dentists a quick, convenient, and short time solution for patient problems. Indications of resilient lining materials are seen in patients with exostosis due to uneven bone resorption, tender soft tissues, bony undercuts, immediate dentures, treatment dentures after implantation or healing period, presence of parafunctional habits, xerostomia, ill fitted dentures, wearing facial prostheses, and demand for better rhythm of chewing strokes. They also compensate for the volumetric shrinkage of acrylic resin $[6,12-15]$. These materials can be provisional or permanent, and auto- or heat-cure-polymerized [16-18]. Five types of 
soft liners exist according to their chemical structures, namely, plasticized acrylic resins (chemical or heat-polymerized), vinyl resins, polyurethane, polyphosphazene, and silicone rubbers (heat-cured or room-temperature-vulcanized) [8]. All types of resilient liner materials have some drawbacks such as insufficient color stability, losing resiliency over time, poor abrasion resistance, presence of surface defects and porosity, water uptake, microbial gathering, bond failures to denture base resin, unsatisfied taste over the time, mephitis, difficulty in cleaning, and premature hardening due to plasticizers solubilization [12, 19-24].

Two-layer dentures can only be successful when there is strong adhesion between different layers of materials [25] Tensile bond strength with a minimum of $0.44 \mathrm{MPa}(4.5 \mathrm{~kg} /$ $\mathrm{cm}^{2}$ ) between acrylic resin and liner is needed to be acceptable for clinical usage [26-28]. To overcome the weak bond strength between denture base resin (DBR) and liners, sandblasting with alumina, laser application, chemical cauterization or primers, acrylic drills, or mesh textured glass fibers have been used by researchers [2, 6, 9, 11, 29-33]. The investigators tried to roughen DBR surface with airborne particles before adding the liners to improve the bond strength [26, 31, 34-37]. Controversy exists regarding efficiency of sandblasting in improving bond strength. While some investigations have shown improved bond strength, $[30,32]$ others have reported that mechanical surface treatment of DBR decreases the adhesion bond strength [21, 25, 29, 31]. Meanwhile, existing reviews evaluated sandblasting without considering the role of sandblasting parameters in the final outcome. The aim of this systematic review was to analyze the effect of sandblasting on bond strength of resilient lining materials applied to DBR considering size of particles in sandblasting, blasting pressure, and type of soft liner.

\section{Materials and Methods}

This systematic review was reported according to the PRISMA (Preferred Reporting Items for Systematic Reviews and Meta-Analyses) statement $[38,39]$. The study design focuses on answering the following question, according to PICO strategy: "what is the effect of sandblasting on bond strength of resilient liners to polymethyl methacrylate (PMMA)?" In this process, the population was denture base resins that were bonded to soft liners; the intervention was sandblasting the substrate; the comparison was made with groups without any surface treatment; and the outcomes were tensile bond strength, shear bond strength, or peel bond strength between acrylic denture base and soft liner. The secondary aim of the study was to answer two further questions: "What is the effect of $\mathrm{Al}_{2} \mathrm{O}_{3}$ particle size and blasting pressure on the bond strength between denture base resin and resilient liner materials?" "How could the type of soft liners affect the bond of sandblasted groups and control groups?" The review question, aims of the study, suitability criteria, search strategy, and data analysis were specified in the beginning with clarity and were included in the study content. A systematic literature search was done in the PubMed, Embase, Cochrane, Scopus, and OpenGrey (https://www.opengrey.eu) databases until January 2020 (Table 1). Furthermore, the reference and citations' lists of the selected articles were reviewed for selecting potential inclusions.

Eligible studies were experimental, in vitro, and laboratory studies which evaluated the bond strength of resilient lining materials (acrylic-based or silicone-based) to polymethyl methacrylate (PMMA) denture base resin and compared no treatment (control) with sandblasting surface pretreatment (experimental) in the same study. In addition, the study should report the mean and standard deviation (SD) of tensile, shear, or peel bond strength. Studies that evaluated other materials for denture base except PPMA, critiques, case reports, systematic reviews, and expert opinion papers were excluded. 38 studies that did not provide essential data after contacting the authors via e-mail were also excluded. Moreover, included studies had to be published in English.

Title, abstract, and full text selection were carried out by two authors (F. H. and M. A.) independently. Finally selected full text studies, based on inclusion and exclusion criteria, were those with proper control group having no surface treatment and with experimental group in which no further treatment, such as applying adhesive, was performed after sandblasting. Disagreements on selection process were resolved by a third investigator (M. H.), and finally consensus was reached through discussion. Two investigators extracted study content and data independently using a standard form prepared in software (Office Excel 2013 software, Microsoft Corporation, Redmond, WA, USA). The following data were extracted: sample size, name of acrylic, liner material, particle size of sandblasting, pressure of sandblasting, time of sandblasting, distance from sandblasting tip to specimen, storage condition of specimen before testing, thermocycling, mean and SD of experimental and control group, and failure mode. Any disagreements between investigators were resolved by discussion. In studies where enough information was not provided, the authors were contacted via e-mail.

Two authors (F. H. and M. H.) evaluated the methodological quality of each enrolled study independently bases on reported tools of previous systematic reviews of in vitro studies. $[40,41]$ Therefore, the following parameters were checked for risk of bias evaluation: specimen randomization, single operator protocol implementation, blinding of the testing machine operator, presence of a control group, standardization of sample preparation, failure mode evaluation, use of materials according to the manufacturer's recommendation, description of sample size calculation, and discarded unacceptable samples. If the article reported the parameter, it received "yes" for that parameter. If information is not provided or the article does not follow the parameters, it received "not mentioned" or "no," respectively. Articles with one to three reported items were considered as high risk of bias, four to five as medium risk of bias, and six to nine as low risk of bias.

For meta-analysis, the outcomes were categorized into three groups of tensile, shear, and peel bond strength. Sandblasted and control groups were analyzed in each 
TABLE 1: Search strategy.

PICO question: what is the effect of sandblasting on bond strength of resilient liners to polymethyl methacrylate (PMMA)?

Items

found

1\# search $(((()(((()((($ “tissue conditioner” [Title/Abstract]) OR "soft liner” [Title/Abstract]) OR "lining material” [Title/Abstract]) OR “denture liner" [Title/Abstract]) OR “resilient liner” [Title/Abstract]) OR “denture reline resin" [Title/Abstract]) OR "definitive silicone-based heat-polymerized" [Title/Abstract]) OR "polymethyl

Population methacrylate" [Title/Abstract]) OR "acrylic resin" [Title/Abstract]) OR "denture base" [Title/Abstract]) OR "heatpolymerized polymethyl methacrylate" [Title/Abstract]) OR ("PMMA [Title/Abstract] AND polyamide" [Title/ Abstract])) OR "denture bases" [MeSH terms]) OR "polymethyl methacrylate" [MeSH terms]) OR "denture liners" [MeSH terms]) OR "tissue conditioning, dental" [MeSH terms]

Search $(((((($ “silicon carbide paper" [Title/Abstract]) OR "surface pre-treatment” [Title/Abstract]) OR "surface Intervention treatment" [Title/Abstract]) OR “pretreated” [Title/Abstract]) OR "silica coating” [Title/Abstract]) OR "sandblasted" [Title/Abstract]) OR "air abrasion" [Title/Abstract]

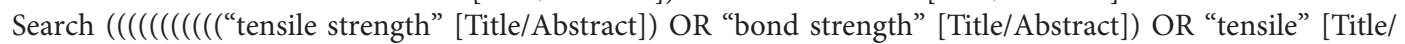
Abstract]) OR “tension bond” [Title/Abstract]) OR “bonding properties” [Title/Abstract]) OR "failure loads” [Title/ Abstract]) OR "peel strength" [Title/Abstract]) OR "failure modes" [Title/Abstract]) OR "mode of failure" [Title/ Abstract]) OR "failures" [Title/Abstract]) OR "tensile strength" [MeSH terms]) OR "shear strength" [MeSH terms]

PubMed

$$
\text { Search (\#1 AND \#2) AND \#3 }
$$

(TITLE-ABS-KEY ((“tissue conditioner”) OR (“soft liner”) OR (“lining material”) OR (“denture liner”) OR (“resilient liner") OR (“denture reline resin”) OR (“definitive silicone-based heat-polymerized”) OR ("polymethyl methacrylate") OR ("acrylic resin") OR ("denture base") OR ("heat-polymerized polymethyl methacrylate") OR (“PMMA AND polyamide”) OR (“denture bases”) OR ("polymethyl methacrylate”)) AND (TITLE-ABS-KEY

Scopus (("silicon carbide paper") OR ("surface pre-treatment") OR ("surface treatment") OR ("pretreated") OR ("silica coating”) OR ("sandblasted”) OR ("air abrasion"))) AND (TITLE-ABS-KEY (("tensile strength") OR ("bond strength") OR (“tensile”) OR (“tension bond”) OR (“bonding properties") OR (“failure loads") OR (“peel strength") OR ("failure modes") OR ("mode of failure") OR (failures)))

((“Tissue conditioner”) OR (“soft liner”) OR ("lining material”) OR (“denture liner”) OR (“resilient liner”) OR (“denture reline resin”) OR (“definitive silicone-based heat-polymerized”) OR ("polymethyl methacrylate”) OR ("acrylic resin") OR ("denture base") OR ("heat-polymerized polymethyl methacrylate") OR ("PMMA" AND

Embase "polyamide") OR ("denture bases") OR ("polymethyl methacrylate”)) AND (("silicon carbide paper") OR ("surface pre-treatment") OR (“surface treatment") OR ("pretreated”) OR (“silica coating”) OR (sandblasted) OR (“air abrasion”)) AND ((“tensile strength") OR (“bond strength”) OR (“tensile”) OR ("tension bond”) OR ("bonding properties") OR (“failure loads") OR (“peel strength”) OR (“failure modes”) OR (“mode of failure”) OR (“failures”)) ((“Tissue conditioner") OR ("soft liner") OR ("lining material”) OR (“denture liner") OR ("resilient liner") OR (“denture reline resin”) OR ("definitive silicone-based heat-polymerized”) OR ("polymethyl methacrylate”) OR ("acrylic resin") OR (“denture base") OR ("heat-polymerized polymethyl methacrylate") OR ("PMMA" AND Cochrane "polyamide") OR (“denture bases") OR ("polymethyl methacrylate")) AND (("silicon carbide paper") OR ("surface
pre-treatment") OR ("surface treatment") OR ("pretreated") OR ("silica coating") OR ("sandblasted") OR ("air abrasion")) AND (("tensile strength") OR ("bond strength") OR (“tensile”) OR ("tension bond”) OR ("bonding properties") OR (“failure loads") OR (“peel strength") OR (“failure modes") OR (“mode of failure”) OR (“failures"))

category both globally and by subgroups. The effect of size of particles on sandblasting, blasting pressure, and type of soft liner was analyzed in subgroups in categories with sufficient data. Studies with several independent experimental and control groups were assumed as independent comparisons in meta-analysis. For studies with multiple correlated comparisons (control group in common), groups were combined with specific formula for mean and SD to create a single pairwise comparison in order to overcome a unit-ofanalysis error.

Meta-analysis was based on inverse-variance method. As $\mathrm{MPa}$ was accepted unit for reporting bond strength values, values of different units were converted to $\mathrm{MPa}$. Bond strength was the continuous outcome evaluated for mean difference (MD) and the corresponding confidence interval. A $p$ value $\leq 0.05$ was considered statistically significant in $Z$ test. Heterogeneity among studies was calculated using $I^{2}$ and $\mathrm{chi}^{2}$ tests. All analyses were done using random effect model in Review Manager software (version 5.1, Cochrane Collaboration, Copenhagen, Denmark).

\section{Results}

The process of screening the articles is summarized in Figure 1 according to PRISMA statement. 106 articles were identified from databases after reading the titles, of these 53 were eligible for full text evaluation. Finally, 37 studies were excluded for the reasons presented in Table 2, and 16 articles were enrolled for meta-analysis. Study characteristics and descriptive evaluation of studies are presented in Table 3.

Overall, eight meta-analyses were done, three global and five subgroup analyses. At the first global analysis for tensile bond strength, 15 pair comparisons from ten studies were analyzed. Results showed that control group had significantly higher bond strength in comparison to blasting group $(p<0.001)$ (Figure 2). At the second analysis, global analysis of shear bond strength was carried out with seven pairs from four articles. In this analysis, statistical difference was found ( $p=0.008)$ favoring the group subjected to sandblasting (Figure 3). The third global analysis of peel strength included four pairs from two articles. The results showed significant 

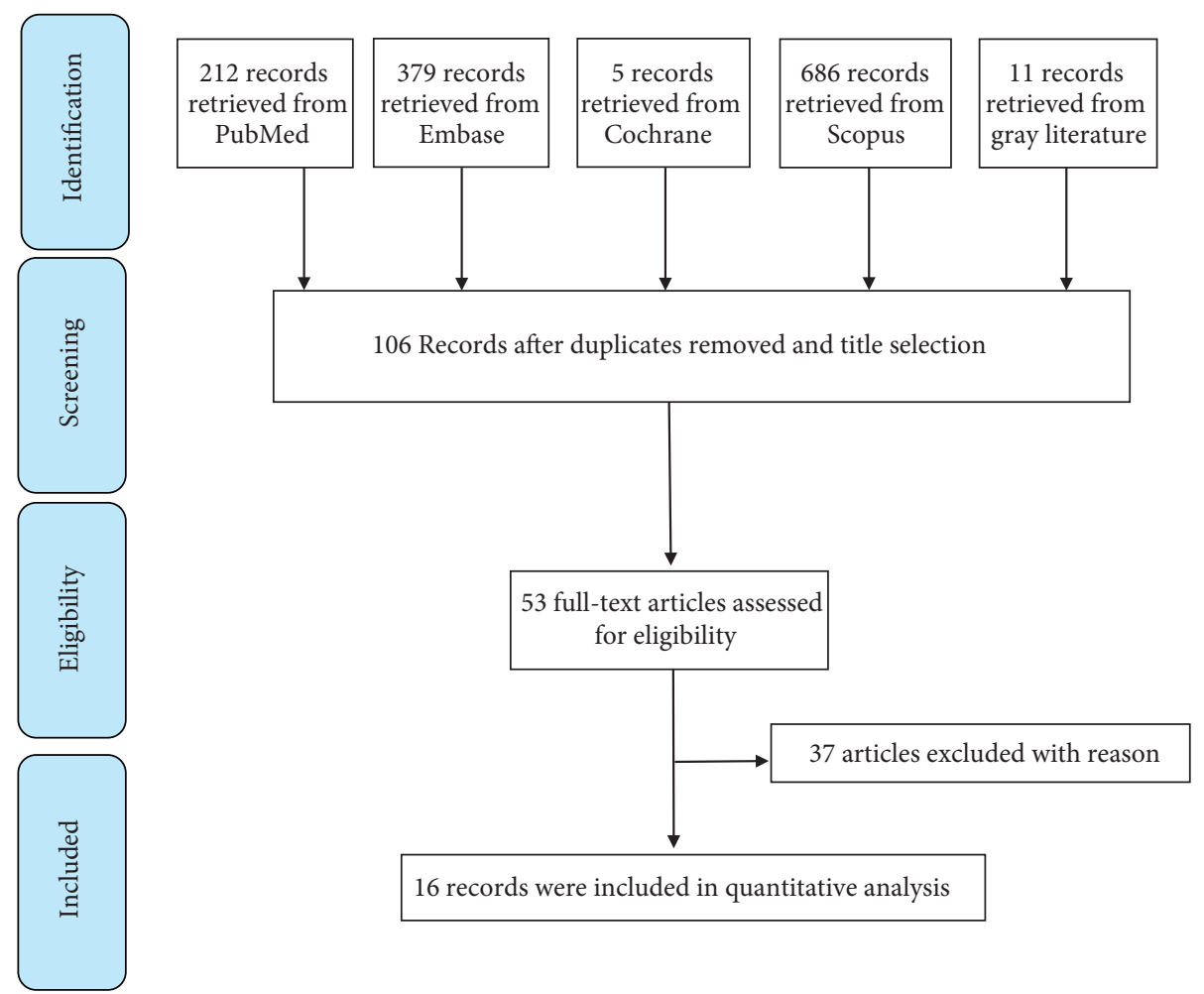

Figure 1: Flow diagram of screening the title, abstract, and full text.

TABLE 2: Excluded studies at the full text level with reasons.

\begin{tabular}{lc}
\hline Reason for exclusion & $\begin{array}{c}\text { Number of excluded } \\
\text { articles }\end{array}$ \\
\hline Not having sandblasted treatment group & $28[2,6,10,42-66]$ \\
Not having any control as untreated group & $3[34,66,67]$ \\
Not using resilient lining material & $3[41,68,69]$ \\
Not related to title & $1[70]$ \\
Not using PPMA & $2[40,71]$ \\
Not reporting enough data & $2[72,73]$ \\
Not reporting SD & $1[74]$ \\
\hline
\end{tabular}

difference between experimental and control group with higher bond strength in control group $(p=0.04)$ (Figure 4$)$. In all analyses $I^{2}$ was beyond 95\%, indicating high heterogeneity.

First subgroup analysis was particle size of sandblasting. The studies were categorized into three groups with strata of small size particle $\left(50 \mu \mathrm{Al}_{2} \mathrm{O}_{3}\right)$, medium size $(50 \mu$ $\mathrm{Al}_{2} \mathrm{O}_{3}<$ particle size $<250 \mu \mathrm{Al}_{2} \mathrm{O}_{3}$ ), and large size (particle size $\geq 250 \mu \mathrm{Al}_{2} \mathrm{O}_{3}$ ). The $\mathrm{MD}$ of subgroups in tensile bond strength is presented in Figure 5. The results favored control group in $5000 \mathrm{a} 0 \mu \mathrm{Al}_{2} \mathrm{O}_{3}$ particle size $(p<0.001)$. However, as the particle size went beyond $50 \mu$, the effect was nonsignificant. In particle size subgroup analysis of shear bond strength, sandblasting with $50 \mu \mathrm{Al}_{2} \mathrm{O}_{3}$ resulted in significantly higher shear bond strength $(p=0.02)$. Groups which were sandblasted with $250 \mu \mathrm{Al}_{2} \mathrm{O}_{3}$ had no significant difference with no treatment specimens (Figure 6). Evaluating the effect of particle size in peel strength resulted in two groups from one study for each of 50 and $250 \mu \mathrm{Al}_{2} \mathrm{O}_{3}$ categories. Korkmaz et al. evaluated the peel strength between control and $50 \mu \mathrm{Al}_{2} \mathrm{O}_{3}$ sandblasting and showed no significant difference. [32] However, when $250 \mu \mathrm{Al}_{2} \mathrm{O}_{3}$ was used for treating the PMMA in Jacobsen's study, the results were significant, favoring sandblasted groups $(p<0.001)$ (Figure 7) [31].

The second subgroup analysis was performed to investigate the effect of blasting pressure. Pair comparison groups were categorized into two strata based on blasting pressure ( 0.2 bar $\leq$ blasting pressure $\leq 1$ bar; 1 bar $<$ blasting pressur$\mathrm{e} \leq 4 \mathrm{bar})$. Meta-analysis showed higher tensile bond strength for control group when the blasting pressure was $\leq 1$ bar $(p<0.001)$. By increasing the blasting pressure beyond 1 bar, sandblasting became significantly more effective than control group $(p=0.03)$ (Figure 8).

The effect of type of soft liner was investigated with strata of silicon-based liner and acrylic resin-based liner. As study groups were not sufficient in shear and peel bond strength categories, this subgroup analysis was only conducted for tensile bond strength. The results showed that groups without any surface treatment had significantly higher tensile bond strength when silicon-based liner was used $(p<0.001)$. Meanwhile, the two studies that used acrylic resin-based liners showed no significant difference between control and sandblasting groups (Figure 9).

Results of quality assessment showed that six studies had medium risk of bias and ten studies had low risk of bias (Table 4). The most not reported items were "single operator protocol implementation" and "blinding of the testing machine operator." 


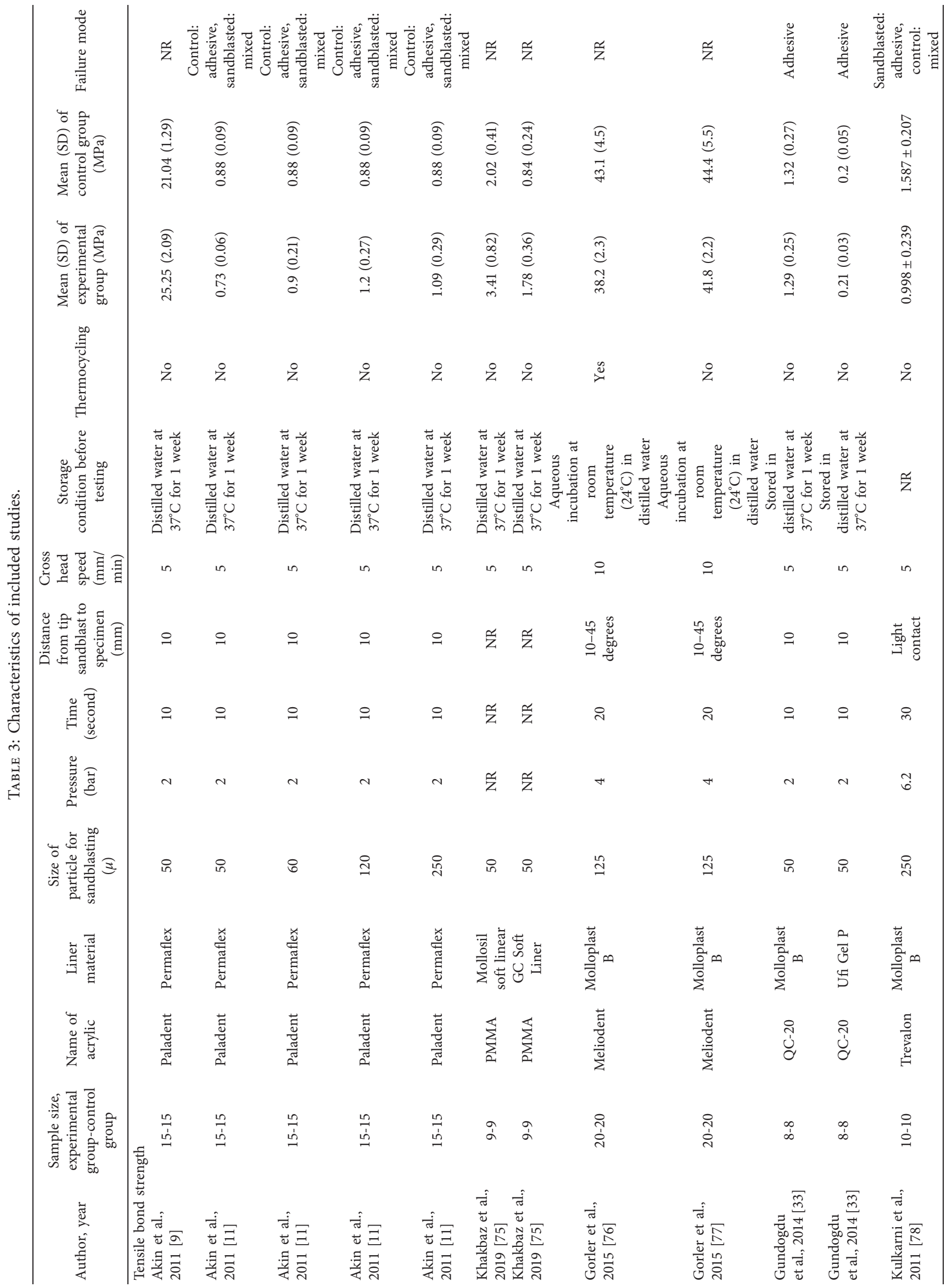




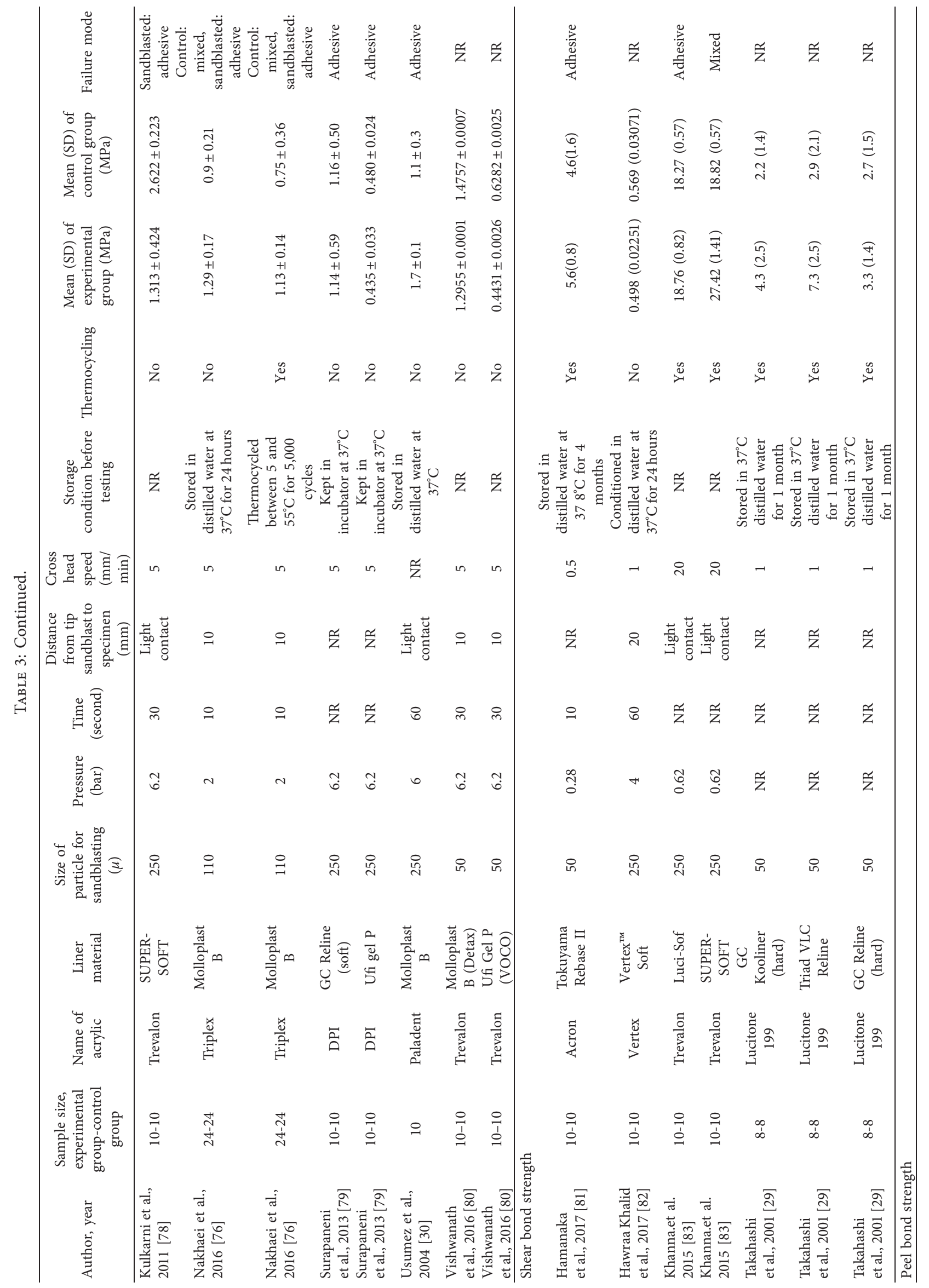




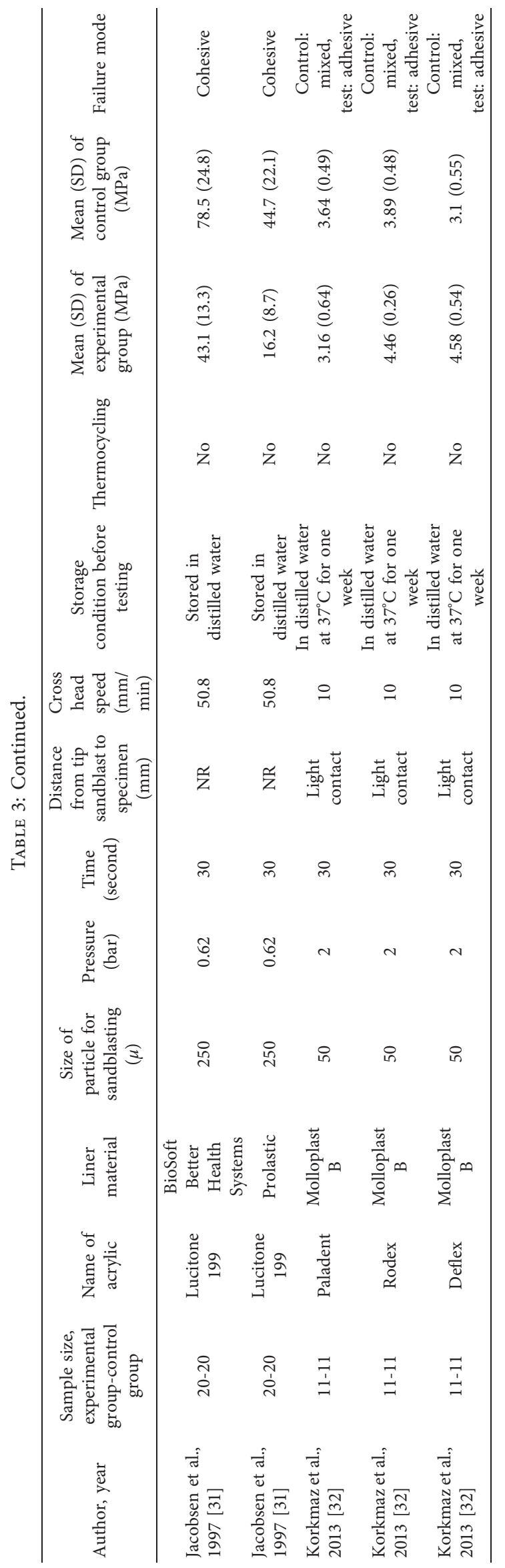




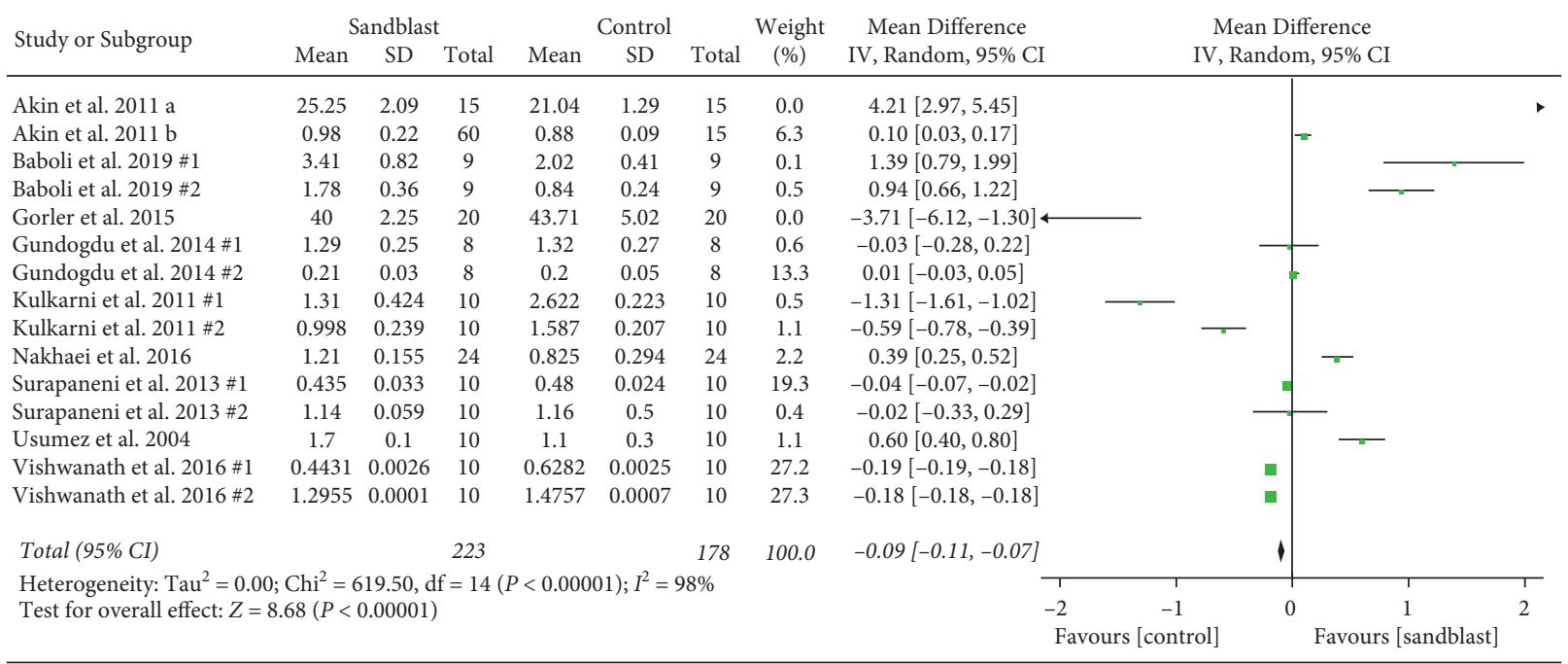

Figure 2: Forest plot for global analysis of tensile bond strength.

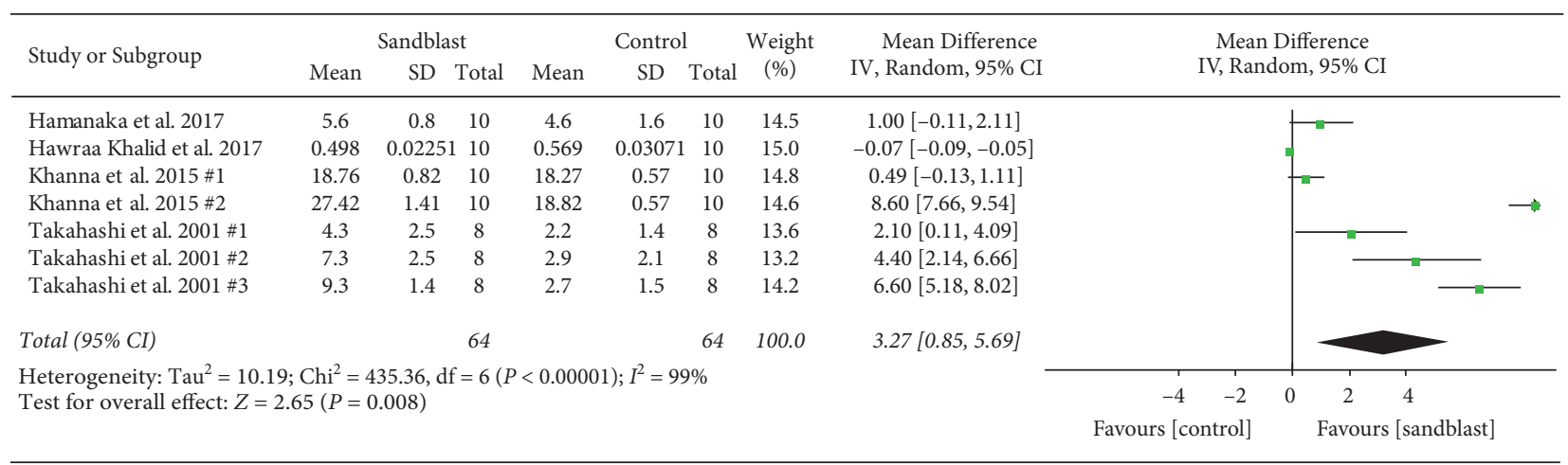

FIGURE 3: Forest plot for global analysis of shear bond strength.

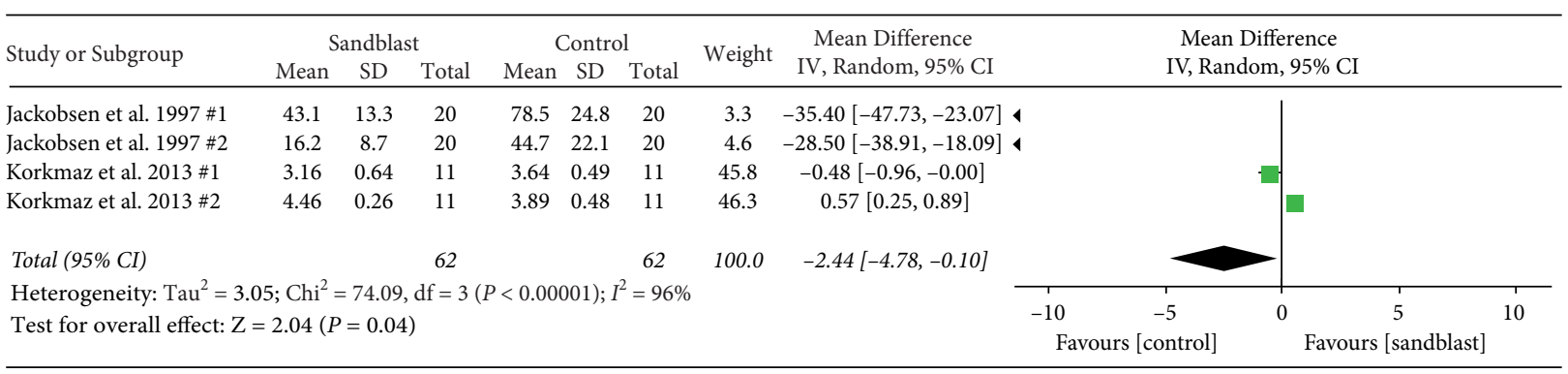

FIGURE 4: Forest plot for global analysis of peel bond strength.

\section{Discussion}

Different methods have been introduced to improve bond of denture base resins to soft liners. The influence of these methods has been evaluated in two systematic reviews. $[84,85]$ The enhancement mechanisms can be divided into three general categories: first, increasing the available surface area for bonding by increasing surface roughness; second, improving the chemical behavior of substrate to improve wettability; and finally establishing hydrogen bond between acrylic group of PMMA and adhesive primers. Treating the surface by laser, sandblasting, and chemical solvent influences the bond strength through increasing surface roughness. The surface of material that is candidate for bonding can be sandblasted by spraying a stream of $\mathrm{Al}_{2} \mathrm{O}_{3}$ particles under high pressure. [86] Global results from two systematic reviews showed that airborne particle abrasion decreases the bond strength between denture base resin and soft liners. [84, 85] However, this result contradicts a number of studies that showed higher bond strength after 


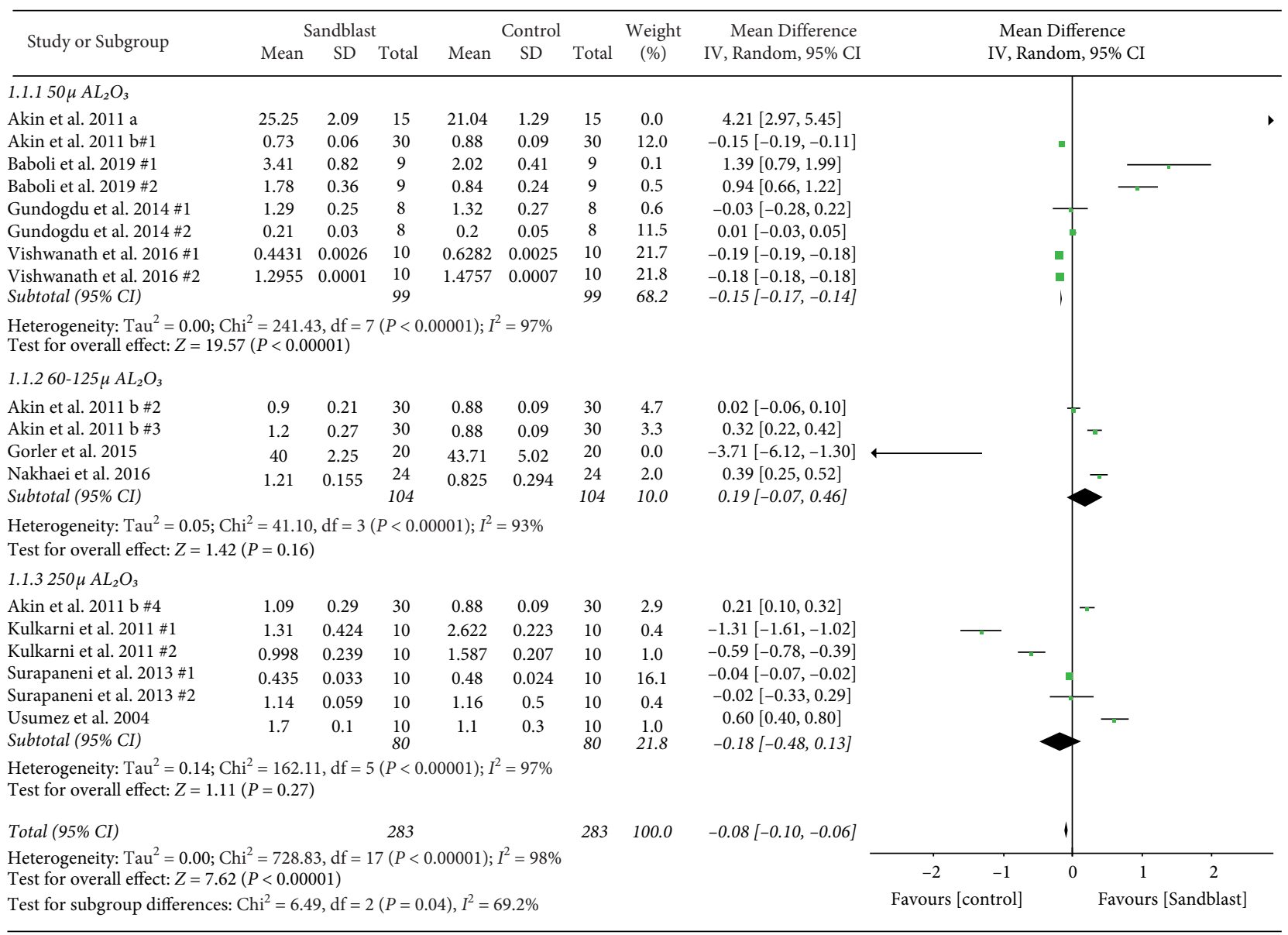

FIGURE 5: Forest plot for subgroup analysis of particle size for tensile bond strength.

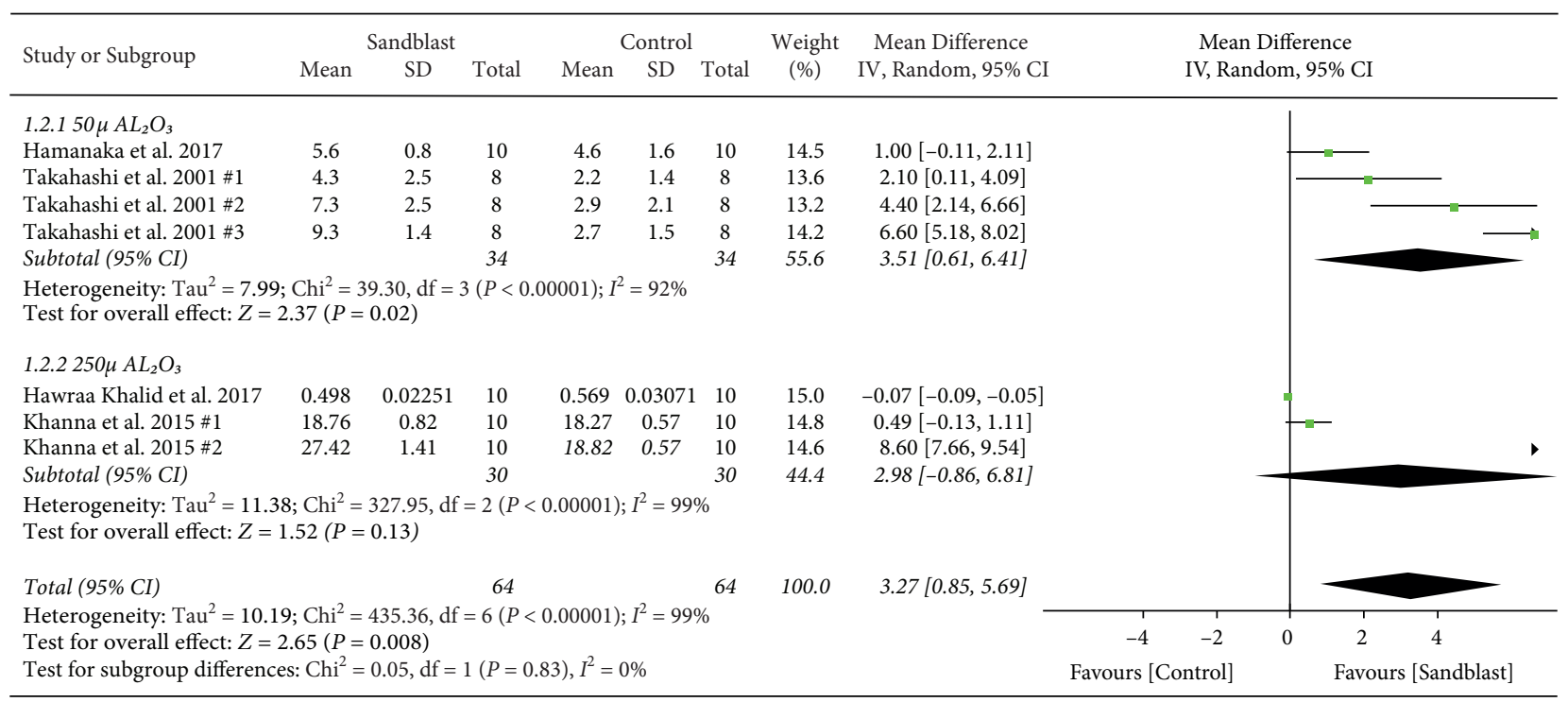

FIGURE 6: Forest plot for subgroup analysis of particle size for shear bond strength. 


\begin{tabular}{|c|c|c|c|c|c|c|c|c|c|c|}
\hline \multirow{2}{*}{ Study or Subgroup } & \multicolumn{3}{|c|}{ Sandblast } & \multicolumn{3}{|c|}{ Control } & \multirow{2}{*}{$\begin{array}{l}\text { Weight } \\
(\%)\end{array}$} & \multirow{2}{*}{$\begin{array}{l}\text { Mean Difference } \\
\text { IV, Random, 95\% CI }\end{array}$} & \multirow{2}{*}{\multicolumn{2}{|c|}{$\begin{array}{l}\text { Mean Difference } \\
\text { IV, Random, 95\% CI }\end{array}$}} \\
\hline & Mean & $\mathrm{SD}$ & Total & Mean & SD & Total & & & & \\
\hline \multicolumn{11}{|l|}{$1.3 .150 \mu \mathrm{AL}_{2} \mathrm{O}_{3}$} \\
\hline Korkmaz et al. $2013 \# 1$ & 3.16 & 0.64 & 11 & 3.64 & 0.49 & 11 & 45.8 & $-0.48[-0.96,-0.00]$ & & \\
\hline Korkmaz et al. 2013 \#2 & 4.46 & 0.26 & 11 & 3.89 & 0.48 & 11 & 46.3 & $0.57[0.25,0.89]$ & & \\
\hline Subtotal $(95 \%$ CI) & & & 22 & & & 22 & 92.1 & $0.06[-0.97,1.09]$ & & \\
\hline \multicolumn{11}{|c|}{$\begin{array}{l}\text { Heterogeneity: } \mathrm{Tau}^{2}=0.51 ; \mathrm{Chi}^{2}=12.80, \mathrm{df}=1(P=0.0003) ; I^{2}=92 \% \\
\text { Test for overall effect: } Z=0.11(P=0.91)\end{array}$} \\
\hline \multicolumn{11}{|l|}{ 1.3.2 $250 \mu \mathrm{AL}_{2} \mathrm{O}_{3}$} \\
\hline Jackobsen et al. $1997 \# 1$ & 43.1 & 13.3 & 20 & 78.5 & 24.8 & 20 & 3.3 & $-35.40[-47.73,-23.07]$ & 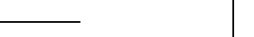 & \\
\hline Jackobsen et al. $1997 \# 2$ & 16.2 & 8.7 & 20 & 44.7 & 22.1 & 20 & 4.6 & $-28.50[-38.91,-18.09]$ & & \\
\hline Subtotal $(95 \%$ CI) & & & 40 & & & 40 & 7.9 & $-31.37[-39.32,-23.42]$ & & \\
\hline \multicolumn{11}{|c|}{$\begin{array}{l}\text { Heterogeneity: } \mathrm{Tau}^{2}=0.00 ; \mathrm{Chi}^{2}=0.70, \mathrm{df}=1(P=0.40) ; I^{2}=0 \% \\
\text { Test for overall effect: } Z=7.73(P<0.00001)\end{array}$} \\
\hline Total $(95 \%$ CI) & & & 62 & & & 62 & 100.0 & $-2.44[-4.78,-0.10]$ & & \\
\hline \multicolumn{8}{|c|}{$\begin{array}{l}\text { Heterogeneity: } \mathrm{Tau}^{2}=3.05 ; \mathrm{Chi}^{2}=74.09, \mathrm{df}=3( \\
\text { Test for overall effect: } Z=2.04(P=0.04) \\
\text { Test for subgroup differences: } \mathrm{Chi}^{2}=58.99, \mathrm{df}=\end{array}$} & & $\begin{array}{cc}-20 & -10 \\
\text { Favours [control] }\end{array}$ & $\begin{array}{l}1020 \\
\text { Favours [sandblast] }\end{array}$ \\
\hline
\end{tabular}

FIgURE 7: Forest plot for subgroup analysis of particle size for peel bond strength.

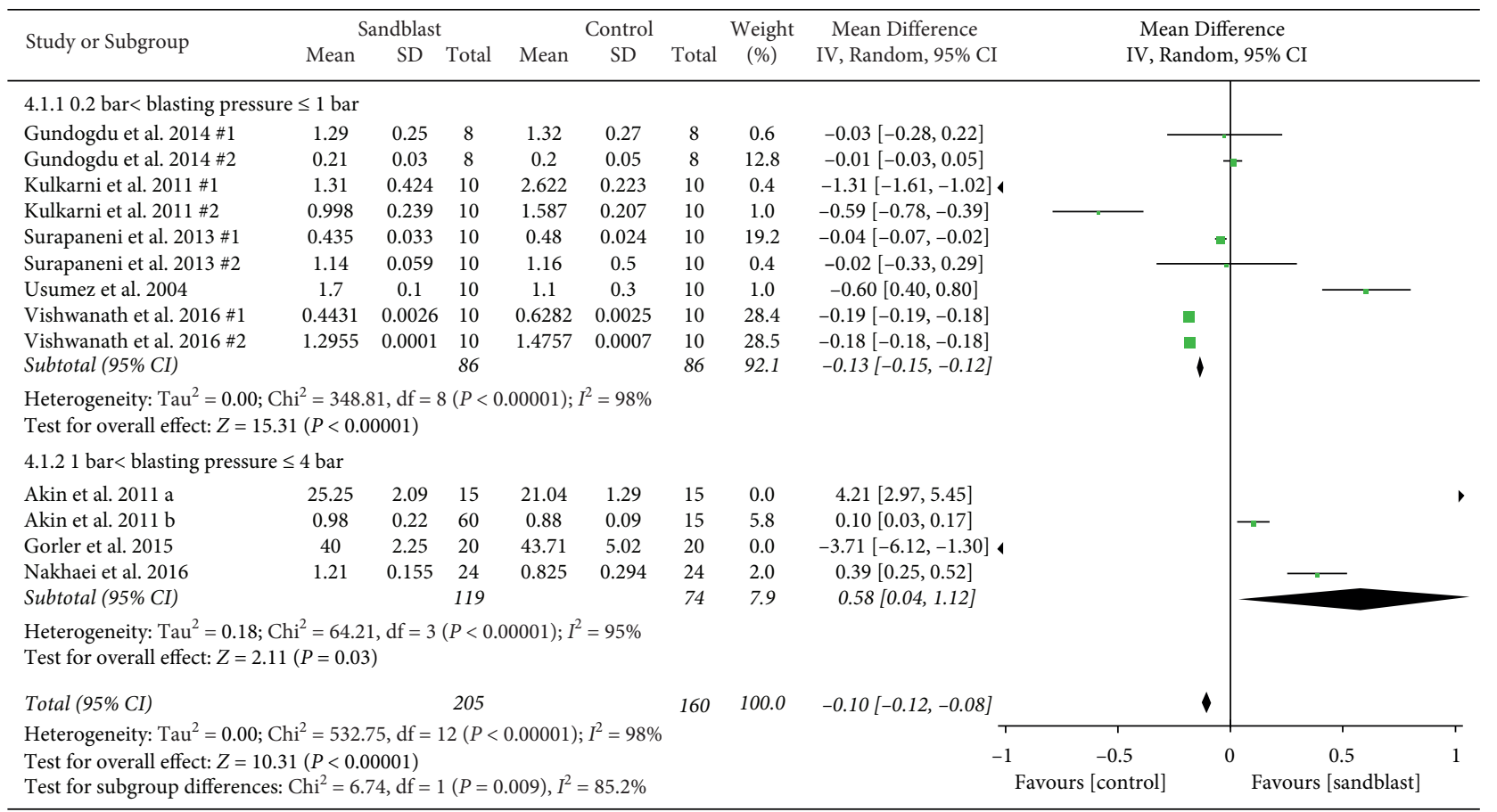

FIGURE 8: Forest plot for subgroup analysis of blasting pressure for tensile bond strength.

sandblasting. [29, 30, 73, 75, 76] Several different parameters and strategies are used for sandblasting, and this could obscure getting the real impact of this procedure on the bond strength. Factors that could affect the bond strength values between the liner materials and denture base resin are the type of lining materials, particle size of sands, blasting pressure and time, test methods, thermocycling, speed of head of testing machine, and thickness of lining material. This review and meta-analysis tried to consider variables in sandblasting including particle size, blasting pressure, and type of liner to identify the effect of this pretreatment in improving bond strength. $[11,15,25,31,33,36,78$, 84, 85, 87-92].
Quality of resilient lining materials is evaluated by their tensile properties. The bond strength between denture base resin and resilient lining materials is usually assessed by tensile test due to reliable results and also easiness of performance. [35, 85, 93] Results of our meta-analysis showed that in general sandblasting could not improve tensile bond strength significantly. Increasing the bond strength after sandblasting is expected as it provides more bonding surface and creates mechanical locks at bond site, also removing contaminants. [29] It results in irregularities, valleys, depressions, many small pits, and scratches in acrylic resin treated surface. $[94,95]$ SEM investigation also shows that sandblasted surfaces are rougher and have no debris. [30] 


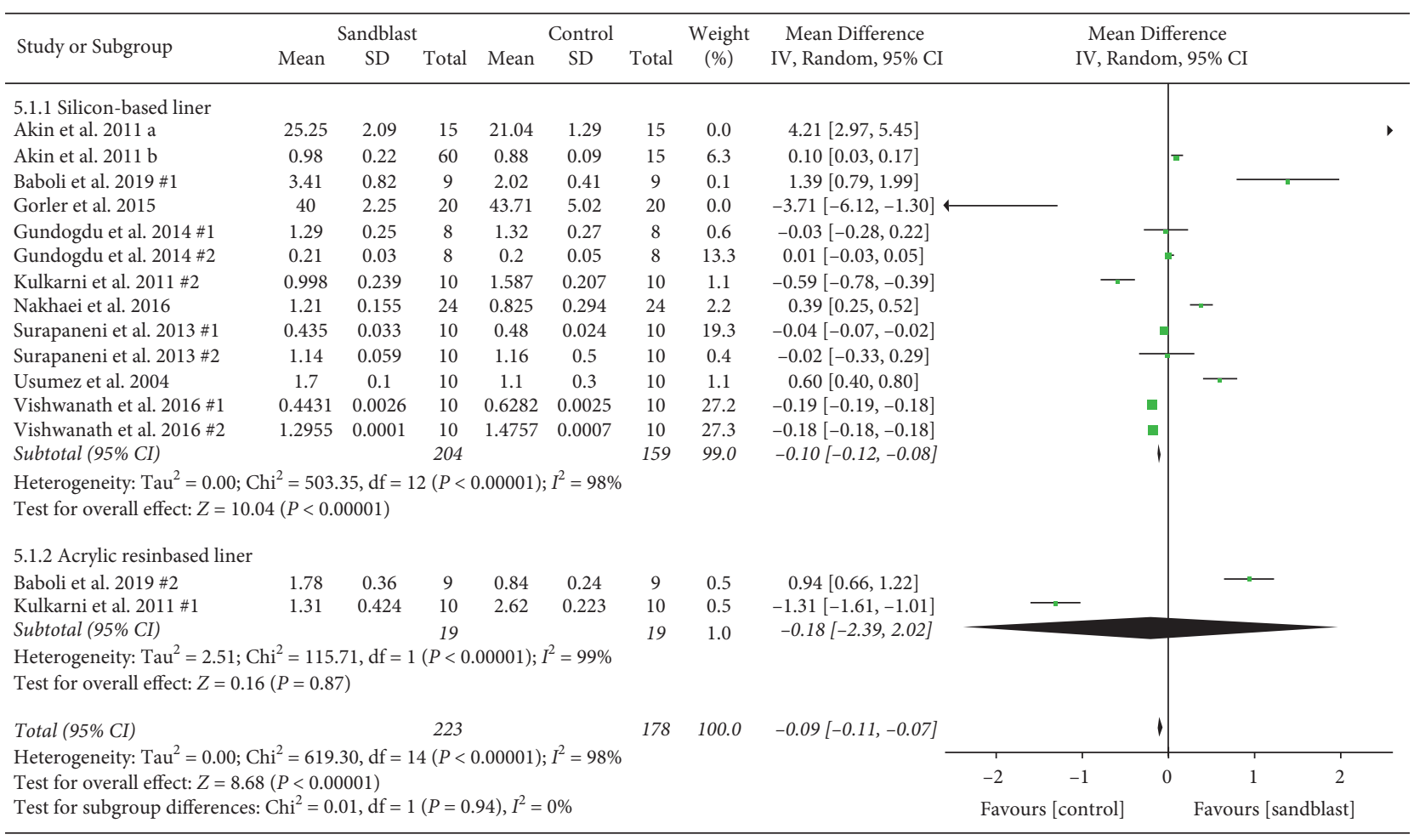

FIGURE 9: Forest plot for subgroup analysis of type of soft liner for tensile bond strength.

Soft lining material could flow into the irregularities of the acrylic resin that resulted in significant effect on adhesive values. [31] However, the size of the irregularities may not be adequate to allow the resilient lining material to penetrate into them without leading to a significant increase in tensile bond strength. [30] As flowing into resin irregularities by the liners is dependent on their viscosity, the liquidity of the elastic materials in a clarified contact angle and surface energy define the penetration. [26, 31] The penetration coefficient (PC) for liquids into a cavity is given by $\mathrm{PC}=\gamma \cos \theta / 2 \eta$, where $\gamma$ is the surface tension, $\theta$ is the contact angle, and $\eta$ is the viscosity. This can state the lower tensile strengths of sandblasted specimens subjected to the reviewed studies. On the other hand, creation of microcracks, vacancies, and voids during packing the resilient lining material on resin surface may trap air bubbles, compensate for the effect of irregularities for increasing the contact surface, and result in reduced bond strength. [35] The other explanation for strength reduction is the stress induced at the junction of PMMA and soft liner, or stress concentration because of discontinuities on the surface. [46] Another hypothesis for reduced bond strength is separated resin or $\mathrm{Al}_{2} \mathrm{O}_{3}$ particles, which remain in the irregularities of the treated surface and will decrease the bond strength. [32] The rate of $\mathrm{Al}_{2} \mathrm{O}_{3}$ adhesion may be varied in the used denture materials.

The results of meta-analysis of two studies showed that sandblasting do not increase peel bond strength; though shear bond strength increased significantly. Al-Athel et al. designed an investigation of the effect of test methods on bond strengths of the liners. [88] They demonstrated that roughening the surface increased shear bond strength while tensile bond strength decreased. [88] Such finding could be explained by the fact that, in roughened surface, more force is needed to move two surfaces along each other as friction is increased. [88] It should be noticed that the distance between the two surfaces and where the force is applied are the most important factors that could affect shear test values. [13] As debonding begins at the edge of the lining materials, the most similar test to intraoral situations for bonded two-layer dentures is peel test. [7, 60, 96] This test directly measures the debonding force, and the site of applying force is closely similar to the real situation in the mouth. [7, 31, 97] However, it is not possible to catch it at the liner acrylic resin interface directly because the possibility of soft liners tearing is high in peel test. [96] Therefore, thickness of liner seems to be critical as cohesive failure is higher. [89, 98, 99] Moreover, surface energy is different in roughened surface and smoothed one. [100] Pretreatment of denture surface affects its geometry that results in alteration of surface energy. $[7,31]$ The amount of force recommended in peeling test is related to surface energy of the used materials, so it should be mentioned accurately.

In this study, the reviewed studies were categorized into three groups with strata of small particle size $\left(50 \mu \mathrm{Al}_{2} \mathrm{O}_{3}\right)$, medium particle size $\left(60 \mu \quad \mathrm{Al}_{2} \mathrm{O}_{3}<\right.$ particle size $<125 \mu$ $\mathrm{Al}_{2} \mathrm{O}_{3}$ ), and large particle size (particle size $\geq 250 \mu \mathrm{Al}_{2} \mathrm{O}_{3}$ ). Studies with small particle size of $\mathrm{Al}_{2} \mathrm{O}_{3}$ (less than $50 \mu \mathrm{m}$ ) showed adverse effect on bond strength of the acrylic resin denture base to resilient material. The result of blasting with particle size in the range of $60 \mu \mathrm{m}$ to $125 \mu \mathrm{m}$ showed increasing bond strength; though the difference was not 
12

International Journal of Dentistry

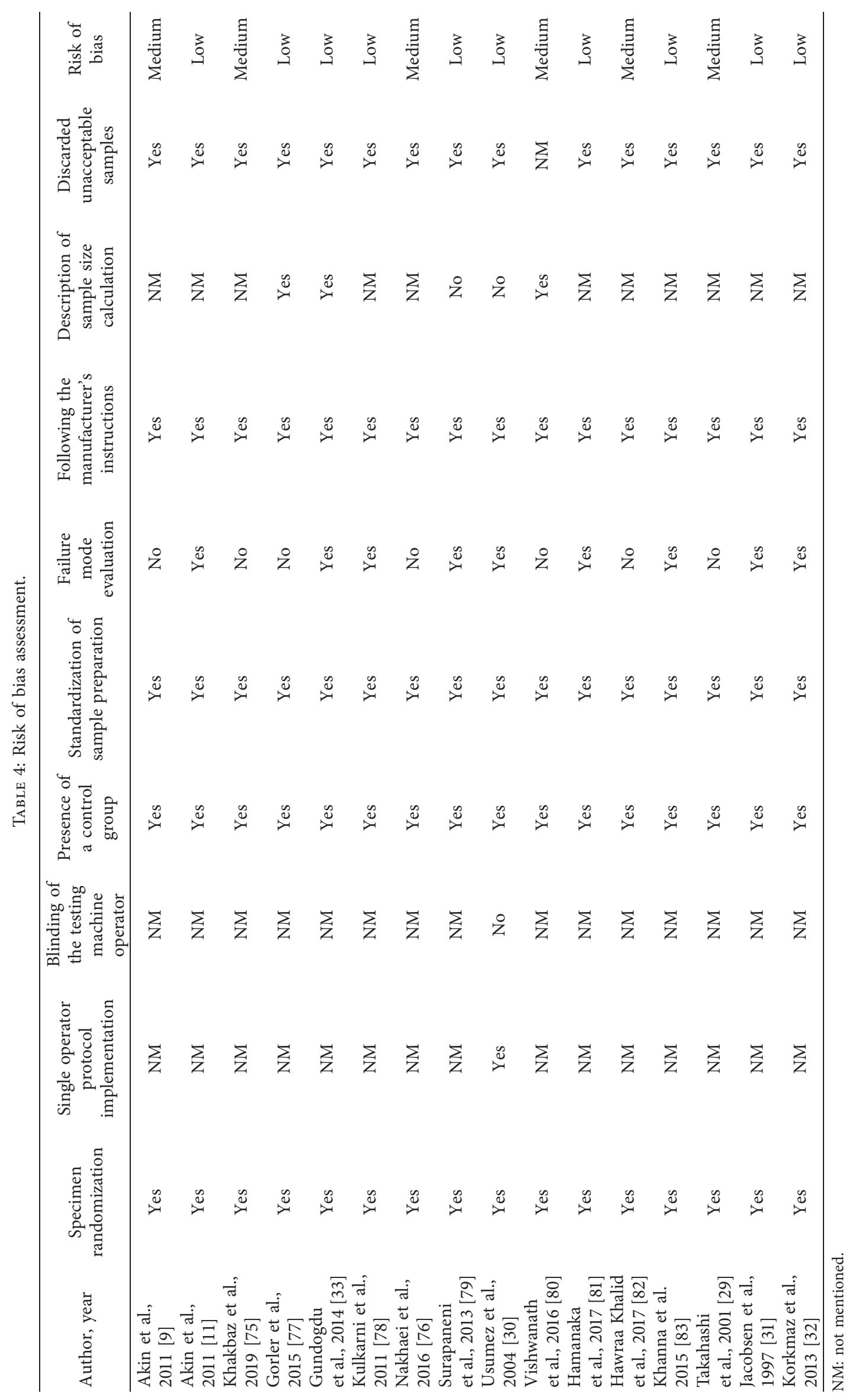


significant. By increasing the particle size to $250 \mu \mathrm{m}$, the results again favored not sandblasted groups. The rationale for these findings is that the size of roughening by sandblasting with $50 \mu \mathrm{m} \mathrm{Al} \mathrm{O}_{3}$ particles may not be sufficient to allow liner material penetration. [31, 62, 76] As the penetration coefficient of the liners is inversely related to their viscosity, liners with higher viscosity have less penetration into PMMA surface pores. [35] On the other hand, sandblasting with large size particles $(250 \mu \mathrm{m})$ also reduces the bond strength due to stress concentration of large size particles. Akin et al. suggested sandblasting with particle size of $120 \mu \mathrm{m}$ in comparison to 50,60 , and $250 \mu \mathrm{m}$ for maximum bonding. [11].

The second subgroup analysis was performed to investigate the effect of blasting pressure. Pair comparison groups were categorized into two strata based on blasting pressure ( 0.2 bar $\leq$ blasting pressure $\leq 1$ bar; 1 bar $<$ blasting pressur$\mathrm{e} \leq 4$ bar). Meta-analysis showed less tensile bond strength for blasted specimens when the blasting pressure was $\leq 1$ bar $(p<0.001)$. By increasing the blasting pressure to more than 1 bar, sandblasting became significantly more effective than control group $(p=0.03)$. This finding can be explained by more irregularities caused by high pressure of sand steam.

Surface treatment should be selected according to the type of the resilient lining material to achieve acceptable bond strength. [85] Among the included studies, nine evaluated silicone-based soft liners, three used acrylic-based resilient liners, and four evaluated both types of liners. The results showed that groups without any surface treatment had significantly higher tensile bond strength when siliconbased liner was used $(p<0.001)$. Meanwhile, the two studies that used acrylic resin-based liners showed contrary results. Khakbaz et al. showed improved bond strength of acrylic soft liner after sandblasting while Kulkarani et al. indicated higher strength in not blasted group. Overall, there is still controversy about the superiority of silicon and acrylic soft liners. Several articles claimed that the similarity of acrylic resin-based liners to denture bases caused higher bond strength values in comparison with silicon-based lining materials. [75, 78, 83] As methyl methacrylate and ethyl methacrylate are monomers that are basically similar, they can mix through polymerization procedure resulting in a copolymer. Silicone liners do not have any chemical bonding to acrylic denture bases because of their structural differences. [31, 78] On the other hand, some studies demonstrated that heat-polymerized silicone-based resilient lining materials had better bond strength than soft liners that contained plasticizer. These heat-polymerized liners had the greatest bond strengths to acrylic resin denture bases, and the autopolymerized silicone liners had insufficient bonding to acrylic base. [25, 87-92] The most important justification in these articles for superior bond strength of silicon liner in comparison to acrylic-based liner was related to minimal water absorption of silicon-based soft liners. [101].

The high level of heterogeneity in analyses indicates great variation of methodology as well as various influencing factors in the main outcome. These factors include type of liner, size of particle, pressure of blasting, speed of head of testing machine, time of blasting, distance from blasting tip to the specimen, storage condition before testing, and thermocycling. The first three items are discussed in this study with quantitative analyses, and the other five items are presented descriptively. A straight correlation between the tensile strength values and the speed of head of testing machine is reported. [88] It has been shown that the amount of tensile strength between acrylic base and resilient lining material increased significantly up to $40 \mathrm{~mm} / \mathrm{min}$ speed of machine head, and after that it had reverse effect. [88] Out of our included studies, nine tested the specimens with universal testing machine at a cross head speed of $5 \mathrm{~mm} / \mathrm{min}$, and two used cross head speed of $10 \mathrm{~mm} / \mathrm{min}$. [9, 11, 33, 75-80] The time of blasting in included studies varied between 10 and 60 seconds, which could be an influencing factor. It has been shown that sandblasting at different distances and angles contributes differences in surface roughness when it is applied to zirconia or titanium materials [102]. However, no study identified the effect of this parameter on the roughness of acrylic resin. Thermocycling also affects the values of bond strength. When resilient liner is immersed in water, it will absorb water and saliva, and the plasticizer and solvent agent will leach out of the liner. The balance between these two mechanisms determines the dimensional stability of the material and bond strength. [16] Two studies evaluated the effect of thermocycling and reported that tensile bond strengths were significantly lower than those in the same sets before thermocycling. [76, 77] Thermocycling could also change the mode of failure to adhesive failure. Nakhaei et al. reported mixed failure for group without thermocycling and adhesive failure for specimen thermocycled between 5 and $55^{\circ} \mathrm{C}$ for 5,000 cycles. [76].

Taking all of these factors into account, it can be concluded that these factors could affect the final outcome, and more in vitro studies with uniform parameters of testing are encouraged to limit the conflicting factors. The authors could not find any clinical studies that compared the effect of sandblasting on the longevity of bond between denture base and liners, and one of the limitation of this study is that the results are based on in vitro studies. Further clinical studies are needed to indicate the long-term effect of sandblasting as a pretreatment surface preparation.

\section{Conclusion}

Within the limitations of this study, these points can be emphasized:

(1) Sandblasting decreases the tensile and peel bond strength of resilient lining materials to denture base resins. However, it improves the shear bond strength.

(2) In $50 \mu \mathrm{Al}_{2} \mathrm{O}_{3}$ particle size, the amount of bond strength of control group is higher than that of experimental group. However, as the particle size goes beyond $50 \mu$, no significant difference exists between the two groups. In particle size subgroup analysis of shear bond strength, sandblasting with $50 \mu \mathrm{Al}_{2} \mathrm{O}_{3}$ resulted in significantly higher shear bond strength. Groups which were sandblasted with $250 \mu$ 
$\mathrm{Al}_{2} \mathrm{O}_{3}$ had no significant difference with no treatment specimen.

(3) Meta-analysis showed higher tensile bond strength for control group when the blasting pressure was $\leq 1$ bar. By increasing the blasting pressure beyond 1 bar, sandblasting became significantly more effective than control group.

(4) Groups without any surface treatment had significantly higher tensile bond strength when siliconbased liner was used, while the two studies that used acrylic resin-based liners showed no significant difference between control and sandblasting groups.

\section{Data Availability}

The data that support the findings of this study are available from the corresponding author upon reasonable request.

\section{Conflicts of Interest}

The authors declare that there are no conflicts of interest regarding the publication of this paper.

\section{References}

[1] D. Anupama, B. Rajendra, S. Veena, C. S. Shastry, and D. Krishna Prasad, “Tissue conditioners: a review," NUJHS, vol. 4, no. 2, pp. 152-157, 2014.

[2] H. Akin, F. Tugut, U. Guney, O. Kirmali, and T. Akar, "Tensile bond strength of silicone-based soft denture liner to two chemically different denture base resins after various surface treatments," Lasers in Medical Science, vol. 28, no. 1, pp. 119-123, 2013.

[3] C. Machado, E. Sanchez, S. S. Azer, and J. M. Uribe, "Comparative study of the transverse strength of three denture base materials," Journal of Dentistry, vol. 35, no. 12, pp. 930-933, 2007.

[4] I. L. Ali, N. Yunus, and M. I. Abu-Hassan, "Hardness, flexural strength, and flexural modulus comparisons of three differently cured denture base systems," Journal of Prosthodontics, vol. 17, no. 7, pp. 545-549, 2008.

[5] J. F. McCabe, T. E. Carrick, and H. Kamohara, "Adhesive bond strength and compliance for denture soft lining materials," Biomaterials, vol. 23, no. 5, pp. 1347-1352, 2002.

[6] M. M. Hatamleh, C. J. Maryan, N. Silikas, and D. C. Watts, "Effect of net fiber reinforcement surface treatment on soft denture liner retention and longevity," Journal of Prosthodontics, vol. 19, no. 4, pp. 258-262, 2010.

[7] A. L. Machado, L. C. Breeding, and A. D. Puckett, "Effect of microwave disinfection on the hardness and adhesion of two resilient liners," The Journal of Prosthetic Dentistry, vol. 94, no. 2, pp. 183-189, 2005.

[8] K. J. Anusavice and R. W. Phillip, Phillip's Science of Dental Materialspp. 751-753, Elsevier, St. Louis, MO, USA, 11th edition, 2003.

[9] H. Akin, F. Tugut, B. Mutaf, G. Akin, and A. K. Ozdemir, "Effect of different surface treatments on tensile bond strength of silicone-based soft denture liner," Lasers in Medical Science, vol. 26, no. 6, pp. 783-788, 2011.

[10] F. Tugut, H. Akin, B. Mutaf, G. E. Akin, and A. K. Ozdemir, "Strength of the bond between a silicone lining material and denture resin after Er: YAG laser treatments with different pulse durations and levels of energy," Lasers in Medical Science, vol. 27, no. 2, pp. 281-285, 2012.

[11] H. Akin, F. Tugut, B. Mutaf, U. Guney, and A. K. Ozdemir, "Effect of sandblasting with different size of aluminum oxide particles on tensile bond strength of resilient liner to denture base," Cumhuriyet Dental Journal, vol. 14, no. 1, pp. 5-11, 2011.

[12] M. I. Hashem, "Advances in soft denture liners: an update," The Journal of Contemporary Dental Practice, vol. 16, no. 4, pp. 314-318, 2015.

[13] M. M. Hatamleh, F. P. Rodrigues, N. Silikas, and D. C. Watts, "3D-FE analysis of soft liner-acrylic interfaces under shear loading," Dental Materials, vol. 27, no. 5, pp. 445-454, 2011.

[14] N. J. A. Jepson, J. F. McCabe, and R. M. Basker, "A new temporary soft lining material," Journal of Dentistry, vol. 23, no. 2, pp. 123-126, 1995.

[15] I. Hayakawa, E.-S. Keh, M. Morizawa, G. Muraoka, and S. Hirano, "A new polyisoprene-based light-curing denture soft lining material," Journal of Dentistry, vol. 31, no. 4, pp. 269-274, 2003.

[16] A. K. Aydin, H. Terzioğlu, A. E. Akinay, K. Ulubayram, and N. Hasirci, "Bond strength and failure analysis of lining materials to denture resin," Dental Materials: Official Publication of the Academy of Dental Materials, vol. 15, no. 3, pp. 211-218, 1999.

[17] D. Sinobad, W. M. Murphy, R. Huggett, and S. Brooks, "Bond strength and rupture properties of some soft denture liners," Journal of Oral Rehabilitation, vol. 19, no. 2, pp. 151-160, 1992.

[18] P. S. Wright, "Composition and properties of soft lining materials for acrylic dentures," Journal of Dentistry, vol. 9, no. 3, pp. 210-223, 1981.

[19] D. W. Jones, G. C. Hall, E. J. Sutow, M. F. Langman, and K. N. Robertson, "Chemical and molecular weight analyses of prosthodontic soft polymers," Journal of Dental Research, vol. 70, no. 5, pp. 874-879, 1991.

[20] A. M. Dimiou, K. Michalakis, and A. Pissiotis, "Influence of thickness increase of intraoral autopolymerizing hard denture base liners on the temperature rise during the polymerization process," The Journal of Prosthetic Dentistry, vol. 111, no. 6, pp. 512-520, 2014.

[21] T. Ohkubo, M. Oizumi, and T. Kobayashi, "Influence of methylmercaptan on the bonding strength of autopolymerizing reline resins to a heat-polymerized denture base resin," Dental Materials Journal, vol. 28, no. 4, pp. 426-432, 2009.

[22] F. E. Izumida, J. H. Jorge, R. C. Ribeiro, A. C. Pavarina, E. B. Moffa, and E. T. Giampaolo, "Surface roughness and Candida albicans biofilm formation on a reline resin after long-term chemical disinfection and toothbrushing," The Journal of Prosthetic Dentistry, vol. 112, no. 6, pp. 1523-1529, 2014.

[23] K. J. Anusavice, C. Shen, and H. R. Rawls, Phillips' Science of Dental Materialspp. 492-494, Elsevier Health Sciences, Amsterdam, Netherlands, 12th edition, 2012.

[24] J. M. F. K. Takahashi, R. L. X. Consani, G. E. P. Henriques, M. A. De Arruda Nóbilo, and M. F. Mesquita, "Effect of accelerated aging on permanent deformation and tensile bond strength of autopolymerizing soft denture liners," Journal of Prosthodontics, vol. 20, no. 3, pp. 200-204, 2011.

[25] Y. Kulak-Ozkan, A. Sertgoz, and H. Gedik, "Effect of thermocycling on tensile bond strength of six silicone-based, resilient denture liners," The Journal of Prosthetic Dentistry, vol. 89, no. 3, pp. 303-310, 2003. 
[26] R. G. Craig and P. Gibbons, "Properties of resilient denture liners," The Journal of the American Dental Association, vol. 63, no. 3, pp. 382-390, 1961.

[27] Z. Khan, J. Martin, and S. Collard, "Adhesion characteristics of visible light-cured denture base material bonded to resilient lining materials," The Journal of Prosthetic Dentistry, vol. 62, no. 2, pp. 196-200, 1989.

[28] F. Kawano, E. R. Dootz, A. Koran, and R. G. Craig, "Comparison of bond strength of six soft denture liners to denture base resin," The Journal of Prosthetic Dentistry, vol. 68, no. 2, pp. 368-371, 1992.

[29] Y. Takahashi and J. Chai, "Assessment of shear bond strength between three denture reline materials and a denture base acrylic resin," The International Journal of Prosthodontics, vol. 14, no. 6, pp. 531-535, 2001.

[30] A. Usumez, O. Inan, and F. Aykent, "Bond strength of a silicone lining material to alumina-abraded and lased denture resin," Journal of Biomedical Materials Research, vol. 71B, no. 1, pp. 196-200, 2004.

[31] N. L. Jacobsen, D. L. Mitchell, D. L. Johnson, and R. A. Holt, "Lased and sandblasted denture base surface preparations affecting resilient liner bonding," The Journal of Prosthetic Dentistry, vol. 78, no. 2, pp. 153-158, 1997.

[32] F. M. Korkmaz, B. Bagis, and M. Özcan, R. Durkan, R. Durkan, S. Turgut, and S. M. Ates, Peel strength of denture liner to PMMA and polyamide: laser versus air-abrasion," The Journal of Advanced Prosthodontics, vol. 5, no. 3, pp. 287-295, 2013.

[33] M. Gundogdu, Z. Yesil Duymus, and M. Alkurt, "Effect of surface treatments on the bond strength of soft denture lining materials to an acrylic resin denture base," The Journal of Prosthetic Dentistry, vol. 112, no. 4, pp. 964-971, 2014.

[34] H. Minami, S. Suzuki, H. Ohashi, H. Kurashige, and T. Tanaka, "Effect of surface treatment on the bonding of an autopolymerizing soft denture liner to a denture base resin," The International Journal of Prosthodontics, vol. 17, no. 3, pp. 297-301, 2004.

[35] W. M. Amin, A. M. Fletcher, and G. M. Ritchie, "The nature of the interface between polymethyl methacrylate denture base materials and soft lining materials," Journal of Dentistry, vol. 9, no. 4, pp. 336-346, 1981.

[36] R. G. Jagger, M. S. Al-Athel, D. C. Jagger, and R. W Vowles, "Some variables influencing the bond strength between PMMA and a silicone denture lining material," The International Journal of Prosthodontics, vol. 15, no. 1, pp. 55-58, 2002.

[37] R. Storer, "Resilient denture base materials. Part I. Introduction and laboratory evaluation," British Dental Journal, vol. 113, pp. 195-203, 1962.

[38] D. Moher, A. Liberati, J. Tetzlaff, D. G. Altman, and PRISMA Group, "Preferred reporting items for systematic reviews and meta-analyses: the PRISMA statement," International Journal of Surgery, vol. 8, no. 5, pp. 336-341, 2010.

[39] A. Liberati, D. G. Altman, J. Tetzlaff et al., "The PRISMA statement for reporting systematic reviews and meta-analyses of studies that evaluate health care interventions: explanation and elaboration," Journal of Clinical Epidemiology, vol. 62, no. 10, pp. 1-34, 2009.

[40] W. L. D. O. Da Rosa, E. Piva, and A. F. Silva, "Bond strength of universal adhesives: a systematic review and meta-analysis," Journal of Dentistry, vol. 43, no. 7, pp. 765-776, 2015.

[41] I. d. O. Nogueira, P. F. G. d. Oliveira, M. B. Magno, D. M. T. P. Ferreira, L. C. Maia, and T. B. Rabello, "Does the application of an adhesive layer improve the bond strength of etched and silanized glass-ceramics to resin-based materials? a systematic review and meta-analysis," The Journal of Prosthetic Dentistry, vol. 125, no. 1, pp. 56-64, 2021.

[42] "United European refractories meet the world," in Proceedings of the Unified International Technical Conference on Refractories 10th Biennial Worldwide Congress, Dresden, Germany, September 2007.

[43] F. T. M. Ariff, N. Yunus, and M. R. Baig, "The effect of mechanical roughening and chemical treatment on shear bond strength of urethane dimethacrylate denture base resin," International Journal of Adhesion and Adhesives, vol. 31, no. 2, pp. 112-118, 2011.

[44] O. H. Bayati, N. Yunus, and S. F. Ahmad, "Tensile bond strengths of silicone soft liners to two chemically different denture base resins," International Journal of Adhesion and Adhesives, vol. 34, pp. 32-37, 2012.

[45] G. Bolayir, H. Demir, A. Dogan, A. Boztuğ, O. Murat Doğan, and K. Soygun, "Effects of different high alkyl methacrylate monomers on tensile bond strength between resilient liner and acrylic resin," Material Research Innovation, vol. 13, no. 4, pp. 431-435, 2009.

[46] G. Bolayir, M. Turgut, I. Hubbezoglu, O. Murat Doğan, A. Dogan, and S. Keskin, "Evaluation of laser treatment on reline-base composites," The Journal of Adhesion, vol. 83, no. 1-3, pp. 117-127, 2007.

[47] Y. W. Cavalcanti, M. M. Bertolini, A. A. Del Bel Cury, and W. J. Da Silva, "The effect of poly (methyl methacrylate) surface treatments on the adhesion of silicone-based resilient denture liners," The Journal of Prosthetic Dentistry, vol. 112, no. 6, pp. 1539-1544, 2014.

[48] H. Demir, K. Soygun, A. Dogan, S. Keskin, O. M. Dogan, and G. Bolayir, "Effect of maleic anhydride pretreatment on tensile bond strength of a silicone soft liner to a denture base polymer," The Journal of Adhesive Dentistry, vol. 13, no. 5, pp. 481-487, 2011.

[49] O. M. Dogan, S. Keskin, G. Bolayir, A. Usanmaz, and B. Bek, "Flexural and bonding properties of a denture base polymer treated with nitric acid or ultraviolet radiation before relining with molloplast-B," The Journal of Adhesive Dentistry, vol. 83, no. 2, pp. 129-137, 2007.

[50] F. S. Fatemi, M. Vojdani, and A. A. R. Khaledi, "The effect of food-simulating agents on the bond strength of hard chairside reline materials to denture base resin," Journal of Prosthodontics, vol. 28, no. 1, pp. 357-363, 2019.

[51] M. C. Goiato, D. M. d. Santos, R. A. d. Medeiros et al., "Tensile bond strength of a soft liner to an acrylic resin after primer application and thermocycling," Materials Research, vol. 18, no. 6, pp. 1183-1187, 2015.

[52] S. Gupta, "Effect of surface treatment on the flexural strength of denture base resin and tensile strength of autopolymerizing silicone based denture liner bonded to denture base resin: an in vitro study," Journal of Indian Prosthodontic Society, vol. 10, no. 4, pp. 208-212, 2010.

[53] S. Gupta, N. D. Wazir, and K. Datta, "Newer method to improve the bond strength of silicone based denture liner- an in vitro study," Medico-Legal Update, vol. 11, no. 2, pp. 61-63, 2011.

[54] H. Kaur and K. Datta, "Comparative evaluation of tensile bond strength of silicone-based denture liners after thermocycling and surface treatment," Indian Journal of Dental Research, vol. 26, no. 5, pp. 514-519, 2015.

[55] A. A. R. Khaledi, M. Bahrani, and S. Shirzadi, "Effect of food simulating agents on the hardness and bond strength of a 
silicone soft liner to a denture base acrylic resin," The Open Dentistry Journal, vol. 23, no. 9, pp. 402-408, 2015.

[56] O. Kumbuloglu, B. Yildirim, N. Al-Haj Hosein, and M. Özcan, "Adhesion potential of relining materials to polyamide and PMMA-based denture base materials: effect of surface conditioning methods," Journal of Adhesion Science and Technology, vol. 23, no. 17, pp. 1939-1974, 2019.

[57] C. M. B. Lael, C. A. Muzilli, and M. E. Miranda, "Effect of superficial treatment on the tensile bond strength of two reliners and a thermopolyrizable resin," Brazilian Journal of Oral Sciences, vol. 6, no. 20, pp. 1295-1300, 2007.

[58] A. N. Louka, H. D. Gesser, and Z. Kasloff, "A laboratory evaluation of the effect of two surface-wetting treatments on soft denture liners," Journal of Dental Research, vol. 56, no. 8, pp. 953-959, 1977.

[59] H. Minami, S. Suzuki, Y. Minesaki, H. Kurashige, and T. Tanaka, "In vitro evaluation of the effect of thermal and mechanical fatigues on the bonding of an autopolymerizing soft denture liner to denture base materials using different primers," Journal of Prosthodontics, vol. 17, no. 5, pp. 392-400, 2008.

[60] R. Osathananada and C. Wiwatwarrapan, "Surface treatment with methyl formate-methyl acetate increased the shear bond strength between reline resins and denture base resin," Gerodontology, vol. 33, no. 2, pp. 147-154, 2016.

[61] H. Patel, C. M. Ravi Kumar, A. A. Ponnanna, S. B. Arvind, K. Shah, and S. Prajapati, "The effect of primer on bond strength of silicone prosthetic elastomer to polymethylmethacrylate: an in vitro study," Journal of Clinical and Diagnostic Research, vol. 9, no. 3, pp. 38-42, 2015.

[62] A. Rhae, B. M. Kumar, and S. C. Ahila, "Evaluation of effect of laser etching on shear bond strength between maxillofacial silicone and acrylic resin subjected to accelerated aging process," Indian Journal of Dental Research, vol. 28, no. 5, pp. 498-502, 2017.

[63] D. Sarac, Y. S. Sarac, T. Basoglu, O. Yapici, and E. Yuzbasioglu, "The evaluation of microleakage and bond strength of a silicone-based resilient liner following denture base surface pretreatment," The Journal of Prosthetic Dentistry, vol. 95, no. 2, pp. 143-151, 2006.

[64] M. Turgut, G. Bolayır, O. M. Doğan, S. Keskin, A. Doğan, and A. Boztuğ, "Bond strength of a silicone soft lining material to poly (methyl methacrylate) resin treated with maleic anhydride and its terpolymers," The Journal of Adhesion, vol. 83, no. 11, pp. 927-938, 2007.

[65] R. F. Zanatta, E. Bresciani, G. R. Batista, E. Crastechini, A. B. Borges, and C. R. G. Torres, "Bond strength of reline resins to aged-simulated denture base acrylic resin," World Journal of Dentistry, vol. 7, no. 1, pp. 1-5, 2016.

[66] Y. Zhang, H. Q. Zhang, J. C. Ma, and S. Y. Jin, "Effect of surface pretreatment with chemical etchants on bond strength between a silicone-based resilient liner and denture base resin," Zhonghua Kou Qiang Yi Xue Za Zhi, vol. 46, no. 12, pp. 762-764, 2011.

[67] S. Atsu and Y. Keskin, "Effect of silica coating and silane surface treatment on the bond strength of soft denture liner to denture base material," Journal of Applied Oral Science, vol. 21, no. 4, pp. 300-306, 2013.

[68] K. Soygan, G. Bolayi, A. Dogan, O. Murat Doğan, H. Demir, and S. Keskin, "The effect of surface treatments on tensile bond strength between a silicone soft liner and a heat-cured denture base resin," The Journal of Adhesion, vol. 87, no. 9, pp. 951-965, 2011.
[69] F. L. Li, Y. Shi, L. Ma, and Y. M. Zhao, "Effect of surface treatment on the bonding of silicone elastomer to acrylic resin," Chinese Journal of Stomatology, vol. 44, no. 9, pp. 558-561, 2009.

[70] M. Mendoca, Y. Cavalcanti, D. Bordin, W. J. Silva, and A. A. Cury, "Candida albicans biofilms and MMA surface treatment influence the adhesion of soft denture liners to PMMA resin," Brazilian Oral Research, vol. 28, no. 1, pp. 61-66, 2014.

[71] H. Minami, S. Suzuki, H. Ohashi, Y. Minesaki, and T. Tanaka, "In vitro evaluation of the bonding of auto-polymerizing soft denture liner to cobalt-chromium alloy," Journal of Oral Rehabilitation, vol. 32, no. 6, pp. 454-460, 2005.

[72] J. Sun, W. J. Lang, J. Li, and F. Q. Zhang, "The influence of bonding strength of denture soft reline resin by different surface treatments," Shang Hai Kou Qiang Yi Xue, vol. 15, no. 2, pp. 149-151, 2006.

[73] J. Philip, D. Ganapathy, and P. Ariga, "Comparative evaluation of tensile bond strength of a polyvinyl acetate-based resilient liner following various denture base surface pretreatment methods and immersion in artificial salivary medium: an in vitro study," Contemporary Clinical Dentistry, vol. 3, no. 3, pp. 298-301, 2012.

[74] C. Swapna, M. T. Hareesh, M. Renijith, A. Ahmed, I. A. Abraham, and M Gopinathan, "An evaluation of the effect of surface treatment on the bond strength of soft denture," Journal of International Oral Health, vol. 8, no. 9, pp. 922-926, 2016.

[75] S. Khakbaz, K. Amirian, M. Rezaei Dastjerdi, and H. Gholinia, "Effect of sandblasting on the tensile bond strength of two permanent silicone soft liners to the denture base," Caspain journal dent research, vol. 8, no. 1, pp. 43-50, 2019.

[76] M. Nakhaei, H. Dashti, F. Ahrari, S. Vasigh, S. Mushtaq, and R. M. Shetty, "Effect of different surface treatments and thermocycling on bond strength of a silicone-based denture liner to a denture base resin," The Journal of Contemporary Dental Practice, vol. 17, no. 2, pp. 154-159, 2016.

[77] O. Gorler, D. O. Dogan, M. Ulgey et al., "The effects of Er: YAG, Nd: YAG, and Ho: YAG laser surface treatments to acrylic resin denture bases on the tensile bond strength of silicone-based resilient liners," Photomedicine and Laser Surgery, vol. 33, no. 8, pp. 409-414, 2015.

[78] R. S. Kulkarni and R. Parkhedkar, "The effect of denture base surface pretreatments on bond strengths of two long term resilient liners," The Journal of Advanced Prosthodontics, vol. 3, no. 3, pp. 16-19, 2011.

[79] H. Surapaneni, P. Ariga, R. Haribabu, Y. Ravi Shankar, V. H. Kumar, and S. Attili, "Comparative evaluation of tensile bond strength between silicon soft liners and processed denture base resin conditioned by three modes of surface treatment: an invitro study," Journal of Indian Prosthodontic Society, vol. 13, no. 3, pp. 274-280, 2013.

[80] S. K. Vishwanath, D. R. Prithviraj, K. Sounder Raj, A. Patel, and S. Saraswat, "The effect of surface pretreatments on the bond strength of soft denture lining materials to heat polymerized polymethyl methacrylate (PMMA) denture base resin-an in vitro study," Journal of Applied Dental and Medical Sciences, vol. 2, no. 4, pp. 32-38, 2016.

[81] I. Hamanaka, H. Shimizu, and Y. Takahashi, "Shear bond strength of an autopolymerizing repair resin to injectionmolded thermoplastic denture base resins," Acta Odontologica Scandinavica, vol. 71, no. 5, pp. 1250-1254, 2013. 
[82] H. Khalid, "Effect of the $\mathrm{CO}_{2}$ laser as surface treatment on the bond strength of heat cured soft liner to the high impact acrylic denture base material," Journal of Baghdad College of Dentistry, vol. 29, no. 1, pp. 20-26, 2017.

[83] A. Khanna, V. M. Bhatnagar, J. T. Karani, K. Madria, and S. Mistry, "A comparative evaluation of shear bond strength between two commercially available heat cured resilient liner and denture base resin with different surface treatment," Journal of Clinical and Diagnostic Research, vol. 9, no. 5, pp. 30-34, 2015.

[84] B. C. Muddugangadhar, D. P. Mawani, A. Das, and A Mukhopadhyay, "Bond strength of soft liners to denture base resins and the influence of different surface treatments and thermocycling: a systematic review," The Journal of Prosthetic Dentistry, vol. 123, no. 6, pp. 30425-30431, 2019.

[85] H. Ozdemir and A. Ozdogan, "Bond strength of resilient lining materials to denture base resin: a systematic review and meta-analysis," Journal of Prosthodontics, vol. 27, no. 9, pp. 1-14, 2018.

[86] K.-H. Chung, C. Y. Chung, C. Y. Chung, and D. C. N. Chan, "Effect of pre-processing surface treatments of acrylic teeth on bonding to the denture base," Journal of Oral Rehabilitation, vol. 35, no. 4, pp. 268-275, 2008.

[87] A. Mese and K. G. Guzel, "Effect of storage duration on the hardness and tensile bond strength of silicone- and acrylic resin-based resilient denture liners to a processed denture base acrylic resin," The Journal of Prosthetic Dentistry, vol. 99, no. 2, pp. 153-159, 2008.

[88] M. S. Al-Athel and R. G. Jagger, "Effect of test method on the bond strength of a silicone resilient denture lining material," The Journal of Prosthetic Dentistry, vol. 76, no. 5, pp. 535-540, 1996.

[89] O. Kutay, "Comparison of tensile and peel bond strengths of resilient liners," The Journal of Prosthetic Dentistry, vol. 71, no. 5, pp. 525-531, 1994.

[90] N. J. Jepson, J. F. McCabe, and R. Storer, "The clinical serviceability of two permanent denture soft linings," British Dental Journal, vol. 177, no. 1, pp. 11-16, 1994.

[91] E. R. Dootz, A. Koran, and R. G. Craig, "Comparison of the physical properties of 11 soft denture liners," The Journal of Prosthetic Dentistry, vol. 67, no. 5, pp. 707-712, 1992.

[92] M. Braden and P. S. Wright, "Water absorption and water solubility of soft lining materials for acrylic dentures," Journal of Dental Research, vol. 62, no. 6, pp. 764-768, 1983.

[93] J. F. Bates and D. C. Smith, "Evaluation of indirect resilient liners for dentures: laboratory and clinical tests," The Journal of the American Dental Association, vol. 70, no. 2, pp. 344353, 1965.

[94] T. J. Emmer, T. J. Emmer, J. Vaidynathan, and T. K. Vaidynathan, "Bond strength of permanent soft denture liners bonded to the denture base," The Journal of Prosthetic Dentistry, vol. 74, no. 6, pp. 595-601, 1995.

[95] P. S. Wright, "Characterization of the rupture properties of denture soft lining materials," Journal of Dental Research, vol. 59, no. 3, pp. 614-619, 1980.

[96] F. Kawano, E. R. Dootz, A. Koran, and R. G. Craig, "Bond strength of six soft denture liners processed against polymerized and unpolymerized poly (methyl methacrylate)," The International Journal of Prosthodontics, vol. 10, no. 20, pp. 178-182, 1997.

[97] P. S. Wright, "Characterization of the adhesion of soft lining materials to poly (methyl methacrylate)," Journal of Dental Research, vol. 61, no. 8, pp. 1002-1005, 1982.
[98] M. S. Al-Athel, R. G. Jagger, and V. Jerolimov, "Bond strength of resilient lining materials to various denture base resins," The International Journal of Prosthodontics, vol. 9, no. 2, pp. 167-170, 1996.

[99] M. M. Mutluay and I. E. Ruyter, "Evaluation of bond strength of soft relining materials to denture base polymers," Dental Materials, vol. 23, no. 11, pp. 1373-1381, 2007.

[100] Y. Tanimoto, H. Saeki, S. Kimoto, T. Nishiwaki, and N. Nishiyama, "Evaluation of adhesive properties of three resilient denture liners by the modified peel test method," Acta Biomaterialia, vol. 5, no. 2, pp. 764-769, 2009.

[101] N. Rajaganesh, S. Sabarinathan, N. S. Azhagarasan, C. Shankar, J. Krishnakumar, and S. Swathi, "Comparative evaluation of shear bond strength of two different chairside soft liners to heat processed acrylic denture base resin: an in vitro study," Journal of Pharmacy \& Bioallied Sciences, vol. 8, pp. S154-S159, 2016.

[102] J. Beatrice, K. James, L. Dan, Y. K. L. Christie, H. M. Wong, and J. P. Matinlinna, "Effects of sandblasting distance and angles on resin cement bonding to zirconia and titanium," International Journal of Adhesion and Adhesives, vol. 62, pp. 25-31, 2015. 